Bożena Matyjas*

ORCID: 0000-0002-8266-7516

Kielce, Polska

\title{
Wizja dziecka i dzieciństwa w ujęciu pedagogiki personalistycznej
}

\section{The Image of Child and Childhood in Personalistic Pedagogy}

\begin{abstract}
The article discusses the image of child and childhood in the contemporary pedagogy, based on philosophical, anthropological and ontological views of personalistic pedagogy. The personalistic pedagogy is grounded in the theory of human being (philosophical anthropology, philosophy of the human person). The person/man/child, understood as a value with such attributes as dignity, autonomy, uniqueness, integrity and rights, is a focus of attention for personalistic pedagogy. In terms of personalistic pedagogy, the child is perceived as the whole (complete) human person. The child, along with his/her childhood, is recognised as a subject/ /co-creator of self-development, growing up, continuous development of human nature, including both one's own well-being and the common/public weal. Family as a natural living environment, plays a key role in the process of child-rearing. The
\end{abstract}

* Prof. dr hab. Bożena Matyjas, Zakład Pedagogiki Społecznej, Instytut Pedagogiki, Wydział Pedagogiki i Psychologii, Uniwersytet Jana Kochanowskiego w Kielcach; email: bozena.matyjas@ujk.edu.pl. 
article considers personalistic pedagogy as an important paradigm of research into the child and childhood.

Keywords: child; childhood; Christian personalism; personalistic pedagogy.

\begin{abstract}
Abstrakt: W artykule przedstawiono wizję dziecka i dzieciństwa w ujęciu pedagogiki współczesnej, a także w oparciu o refleksję filozoficzno-antropologiczną i ontologiczną pedagogiki personalistycznej. Jej podstawę stanowi teoria bytu osobowego (filozoficzna teoria człowieka); w centrum zainteresowań pedagogiki personalistycznej jest zatem osoba/człowiek/dziecko ujmowane jako wartość, której przypisana jest godność, autonomia, niepowtarzalność, integralność, prawa. Koncepcja ta buduje całościową (kompletną) wizję dziecka jako osoby ludzkiej. Dziecko, jego dzieciństwo ujmowane jest jako podmiot/współtwórca własnego rozwoju, wzrastania, doskonalenia się w „człowieczeństwie”, z uwzględnieniem dobra własnego oraz wspólnego/społecznego. W procesie wychowania dziecka kluczową rolę przypisuje się rodzinie jako naturalnemu środowisku jego życia. Pedagogikę personalistyczną potraktowano w niniejszym artykule jako ważny paradygmat badań dziecka i dzieciństwa.
\end{abstract}

Słowa kluczowe: dziecko; dzieciństwo; personalizm chrześcijański; pedagogika personalistyczna.

\title{
1. Wprowadzenie
}

Współczesną wizję dziecka i dzieciństwa należy rozpatrywać w aspekcie przednaukowej i naukowej refleksji pedagogicznej. Naukowa refleksja pedagogiczna, która zrodziła się stosunkowo niedawno - w XIX wieku rozpoczęła nowy dyskurs nad dzieckiem i dzieciństwem.

Zmiany w postrzeganiu dziecka, a tym samym jego dzieciństwa, zachodziły bardzo wolno. Stopniowo też przebiegał proces upodmiotowienia dziecka. Zawsze kontekstem owej refleksji była kultura, społeczeństwo, historia ludzkości/człowieka. Nie można bowiem rozpatrywać problematyki dziecka, dzieciństwa w oderwaniu od historii człowieka, rodziny, danego społeczeństwa czy narodu (Matyjas, 2008, s. 13). W swoich rozważaniach chciałabym skupić się na współczesnym rozumieniu kategorii dziecka i dzieciństwa, obejmującym trzy ostatnie dekady. Zaproponowaną cezurę czasową należy wiązać z rozwijającymi się od tego czasu badaniami dzieciństwa na gruncie 
polskiej pedagogiki, zwłaszcza pedagogiki społecznej. Niewątpliwie duży udział w takim rozumieniu dziecka w społeczeństwie miały badania Barbary Smolińskiej-Theiss, która w 1993 opublikowała monografię pt. Dzieciństwo w matym mieście (Smolińska-Theiss, 1993). Wprawdzie zainteresowanie dzieckiem i dzieciństwem, ponowne odkrycie tej problematyki w ujęciu teoretycznym i empirycznym/badawczym nastąpiło w Europie w latach sześćdziesiątych XX wieku, ale w Polsce dopiero dwie dekady później tj. w latach osiemdziesiątych i dziewięćdziesiątych. Nie oznacza to jednak, że naukowa refleksja dotycząca dziecka, dzieciństwa nie była podejmowana wcześniej przez rozwijające się od końca XIX wieku nauki społeczne, zwłaszcza psychologię, socjologię czy pedagogikę. Należy tu jednak wskazać, że dopiero trzy dekady temu rozpoczął się w Polsce nowy dyskurs o dzieciństwie, w którym dziecko postawione zostało w centrum zainteresowań pedagogów.

We współczesnej pedagogice rozpatruje się dziecko, dzieciństwo odnosząc je do orientacji humanistycznej, według której dzieciństwo jest wartością, a dziecko osobą obdarzoną godnością i wolnością, której przysługują określone prawa. Dziecko ujmowane jest tutaj jako podmiot rozwoju zakorzeniony w kulturze i historii, jako twórca własnej przestrzeni życia (dziecko jako humanum). Można postawić tezę, iż współczesne podejście do dziecka nastawione jest „na dziecko” i „ku dziecku”. Nowy paradygmat w badaniach nad dzieckiem i dzieciństwem należy łączyć z przemianami demokratycznymi w wielu krajach (w Polsce od roku 1989), które przyczyniły się do traktowania dziecka jako podmiotu świata społecznego, z uwzględnieniem jego statusu, praw, własnej partycypacji w życie własne i społeczne, w tym rodzinne, szkolne, środowiskowe. Nie bez znaczenia był także rozwój psychologii, socjologii czy pedagogiki jako nauk społecznych, w których człowiek oraz jego wszechstronny i integralny rozwój stały się podstawą dla badaczy podejmujących zagadnienie dzieciństwa.

W nowym rozumieniu dziecka i dzieciństwa na gruncie pedagogiki (społecznej) widoczne jest podmiotowe/osobowe podejście do dziecka. Należy nadmienić, że jest ono zbieżne z założeniami pedagogiki personalistycznej, która zakłada, że człowiek jest osobą - autonomiczną, posiadającą godność i rozum (Godawa, 2017, s. 327). Personalistyczna koncepcja ujmowania dziecka jako osoby oparta jest o filozoficzną (antropologiczną) teorię osoby (Nowak, 1999, s. 295), zwłaszcza o założenia filozofii chrześcijańskiej. Katarzyna Segiet wskazuje właśnie na chrześcijaństwo, które wniosło/wnosi do dyskursu pedagogicznego koncepcję człowieka, świata i życia oraz spojrzenia na podstawowe wartości (Segiet, 2011, s. 37). Wynika z niej, że personalistyczne spojrzenie na człowieka to uznanie, że dziecko jest osobą, ma 
nieocenioną wartość, przypisaną mu godność, niepowtarzalność czy niezbywalne prawa, tkwiące w naturze ludzkiej. Dziecko jako osoba oczekuje od dorosłych wypełniania wobec niego powinności związanych z opieką, wychowaniem i edukacją.

Warto w tym miejscu podkreślić, że pojęcie osoby ludzkiej implikuje pojęcie dziecka, wizję dzieciństwa. Wskazuje na podmiotowe i integralne ujmowanie dziecka w procesie jego rozwoju i wychowania, które obejmuje wszystkie wymiary człowieka/dziecka jako osoby:

- strukturalny (dziecko tworzy psychofizyczną i substancjalną jedność),

- społeczny (dziecko jako istota społeczna, relacyjna z innymi osobami) oraz

- transcendentny (kierowanie się ku Bogu, duchowa natura człowieka/dziecka) (Śliwerski, 2012, s. 64).

Pedagogika personalistyczna w swojej genezie chrześcijańskiej odnoszącej się do grecko-rzymskiej tradycji filozoficznej eksponuje osobę ludzką jako podmiot zaangażowany w proces socjalizacji, kształcenia i wychowania. Jak zauważa Marian Nowak, afirmuje się tu godność, rozumność, wolność, zdolność do miłości każdej osoby, każdy bowiem podmiot osobowy posiada w sobie walor niepowtarzalny i nadrzędny wobec wszystkich wartości materialnych, ekonomicznych i społeczno-politycznych (Nowak, 1996, s. $31-51)$.

Poznanie wizji dziecka i dzieciństwa w ujęciu pedagogiki personalistycznej jest istotne dla pedagogiki i jej różnych subdyscyplin, szczególnie dla pedagogiki społecznej, ponieważ stanowi dla wielu badaczy - pedagogów podstawę konstruowania i projektowania badań/obrazów dzieciństwa w oparciu o paradygmat, który w znaczący sposób wpływa na sposoby myślenia o dziecku, jego różnorodnych możliwościach i kompetencjach, jego edukacji, prawach, miejscu w społeczeństwie (Szczepska-Pustkowska, 2012, s. 36).

W ocenie autorki prezentowanego artykułu związek pedagogiki (społecznej) z pedagogiką personalistyczną (wybranymi jej aspektami i wymiarami) jest wyraźny, ponieważ

w personalizmie uprzywilejowane miejsce zajmuje myślenie egzystencjalne i antropologiczne, a poprzez to także pedagogiczne. Personalizm przyjmuje bowiem postawę otwarcia na egzystencję ujmowaną w wymiarze przestrzenno-czasowym. Eksponuje także wątek porzucenia statycznej koncepcji osoby i skierowania ku dynamicznym determinantom życia osobowego (Nowak, 2006, s. 232). 
Podobne ujęcie, w którym podkreśla się koncepcję osoby (dziecka) odnosząc ją do danego czasu i przestrzeni, wskazując przy tym na różne czynniki ją kształtujące, w tym własną aktywność podmiotu/dziecka, widoczne jest w badaniach dzieciństwa na gruncie pedagogiki społecznej.

Dostrzegając wzajemne związki dotyczące pedagogiki (społecznej) i pedagogiki personalistycznej w zakresie konstruowania/przedstawiania dziecka i dzieciństwa, chciałabym w toku dalszych rozważań odpowiedzieć na następujące pytania: jaka wizja dziecka i dzieciństwa dominuje we współczesnym dyskursie pedagogicznym?, jaką wizję dziecka i dzieciństwa proponuje pedagogika personalistyczna? Należałoby tu podkreślić, iż odpowiedzi na te pytania są istotne dla pedagogiki, zwłaszcza pedagogiki społecznej, której jestem reprezentantką, zarówno w wymiarze teoretycznym (założeń), jak i wymiarze badawczym.

\section{Wizja dziecka i dzieciństwa we współczesnym dyskursie pedagogicznym}

Rozważania dotyczące wizji dziecka i dzieciństwa na gruncie pedagogiki (społecznej) rozpocznę od wyjaśnienia tych dwóch kluczowych, wykorzystywanych w dalszej dyskusji pojęć, tj. dziecka i dzieciństwa. Są one bowiem ściśle ze sobą powiązane. Zacznę od pierwszego z wymienionych pojęć - dziecka. W świetle europejskiego i polskiego prawa dzieckiem jest osoba do 18. roku życia. Takie stanowisko można znaleźć między innymi w Konwencji o prawach dziecka, gdzie czytamy, że dzieckiem jest każda istota ludzka poniżej 18 lat (Łopatka, 2000, s. 8). W tym ujęciu dla określenia tożsamości podmiotu/dziecka zastosowano kryterium wieku. A zatem na gruncie prawa dziecko uznawane jest jako osoba ludzka (podmiot) od urodzenia do uzyskania przez nie pełnoletniości. Podobne ujęcie występuje także w pedagogice i psychologii (zwłaszcza rozwojowej). Dziecko oznacza tutaj „człowieka w pierwszym okresie rozwoju osobniczego, od chwili urodzenia do zakończenia procesu wzrastania" (Milerski i Śliwerski, 2000, s. 51), który określany jest także jako adolescencja (u dziewcząt to przedział pomiędzy 11 a 16 rokiem życia, u chłopców - 13 a 18 rokiem życia) (tamże, s. 52). A zatem, na gruncie pedagogiki i psychologii, także prawa, dzieckiem określa się człowieka od narodzin do uzyskania dorosłości, tj. ukończenia 18 lat.

Moje zainteresowania badawcze dotyczą pedagogiki dziecka, która określa je jako osobę znajdującą się w okresie rozwojowym nazywanym dzieciń- 
stwem - to drugie z wymienionych powyżej pojęć, które należy tu zdefiniować. Dzieciństwo uznawane jest w literaturze pedagogicznej (także w innych naukach społecznych) jako specyficzny czas w życiu jednostki, którym zajmuje się wielu pedagogów w swoich pracach teoretyczno-badawczych. I tak np. Jadwiga Izdebska określa dzieciństwo jako

etap psychologiczno-rozwojowy, wychowawczy oraz społeczno-historyczny w życiu człowieka; w szerszym znaczeniu obejmuje okres od urodzenia do adolescencji; jako suma doświadczeń dziecka stanowi fundament wspomagający okresy po nim następujące; realizuje się w określonych warunkach biologiczno-rozwojowych, społeczno-kulturowych, religijno-sakralnych wpływających na jakość i wartość życia człowieka; zjawisko historyczno-społeczno-kulturowe opisujące sytuacje oraz warunki społeczne życia dziecka w różnego typu środowiskach społecznych (Izdebska, 2016, s. 305).

Przedstawiona powyżej definicja dzieciństwa akcentuje tak ważne dla pedagogiki (zwłaszcza pedagogiki społecznej) stanowisko wskazujące na społeczno-kulturowe uwarunkowania dzieciństwa, które ujmuje się tutaj integralnie, nie tylko w wymiarze jednostkowym, osobowym (dziecko to psychofizyczna jedność), ale także środowiskowym (komplementarne oddziaływanie na dziecko i jego dzieciństwo wszystkich środowisk wychowawczych tj.: rodziny, szkoły, środowiska lokalnego, mass mediów, itd.). Badania uwzględniające wszystkie wymienione aspekty rozumienia dzieciństwa prowadzili i nadal prowadzą np.: Katarzyna Segiet (2000, 2007, 2010, 2011), Barbara Smolińska-Theiss (1993, 1995, 2010, 2014), Bożena Matyjas (2003, 2008, 2012, 2017), Maria Szczepska-Pustkowska (2009, 2011, 2012), Ewa Jarosz (2017, 2018).

Warto przypomnieć, że wiek dziecka wyznacza przypisane do każdego etapu dzieciństwa zadania rozwojowe. W literaturze pedagogicznej, także psychologicznej, wskazuje się, że etapy dzieciństwa (długość ich trwania) są umowne, ponieważ każde dziecko rozwija się indywidualnie, w swoim uwarunkowanym biologicznie i społecznie tempie, które nie zawsze można zakwalifikować do danego do wieku dziecka etapu. Bogusław Śliwerski uważa, że danemu etapowi życia człowieka (zwłaszcza dzieciństwu) powinny być przypisane konkretne zadania rozwojowe (Śliwerski, 2007, s. 25). Wyróżnienie owych zadań jest szczególnie ważne dla okresu niemowlęctwa i wczesnego dzieciństwa, a także średniego dzieciństwa oraz adolescencji.

Pojęcie dziecka i dzieciństwa konstruowane jest w pedagogice współczesnej w oparciu o wiedzę z zakresu innych nauk. Widoczne jest tutaj wyraźne 
nawiązanie do dorobku i osiągnięć takich nauk jak: filozofia, antropologia, socjologia, psychologia, historia czy biologia (Segiet, 2011, s. 19-162).

Należy jednak podkreślić, że studia dotyczące dziecka i dzieciństwa odnoszą się głównie do filozofii jako nauki/wiedzy o człowieku. Kluczowe dla rozumienia pojęcia człowieka jest pojęcie osoby ludzkiej - tutaj można by doszukiwać się zrozumienia kategorii dzieciństwa. Maria Szczepska-Pustkowska wskazała na filozofię dzieciństwa (bezpośrednio związaną z filozofią jako nauką) jako prolegomenę do każdej filozofii dziecka - także w paradygmacie filozofii chrześcijańskiej/personalistycznej (Szczepska-Pustkowska, 2011, s. 24 i nn.).

Filozofia jako nauka zajmująca się poznawaniem, człowiekiem i rzeczywistością, w której on egzystuje, dostarcza wiedzę niezbędną dla pedagogiki/ /pedagogów - teoretyków i praktyków wychowania. Na wzajemne związki filozofii i pedagogiki wskazuje m. in. Witold Starnawski, który stwierdza, że

„użyteczność” filozofii dla pedagogiki wyraża się m. in. w:

a) namyśle nad meta-zasadami pedagogiki;

b) krytycznej refleksji nad przyjmowanymi paradygmatami, metodami;

c) umiejętności stosowania pozytywnego kryterium (kryteriów) i ocenie jego efektywności;

d) próbie zrozumienia ambiwalencji, antynomii, paradoksów tkwiących i w człowieku, i w samym procesie wychowania;

e) pobudzeniu pedagoga do autorefleksji (Starnawski, 2014, s. 81-84).

Powyższe stanowisko można odnieść także do pedagogicznych studiów nad dzieckiem i jego dzieciństwem, przedstawianiem ich wizji, która pozwala sformułować fundamentalną bazę pojęciową, umożliwiającą klarowny opis rzeczywistości (pedagogicznej). Zasadne wydaje się być odwołanie pedagogiki do filozofii, ponieważ pozwala odpowiedzieć na pytania: kim jest człowiek? kim jest dziecko? Odwołanie się do filozofii, w tym przypadku filozofii personalizmu, jest bardzo ważne, ponieważ pozwala wprowadzić na grunt pedagogiki pojęcie osoby ludzkiej, które jest dla niej kluczowe. Pojęcie osoby wydaje się być niezbędne przy opisie, a także wyjaśnianiu zagadnienia dotyczącego wizji dziecka i dzieciństwa. Jak dowodzi Katarzyna Segiet, to właśnie pojęcie osoby ludzkiej implikuje pojęcie dziecka, a tym samym spojrzenie współczesnej pedagogiki na dzieciństwo (Segiet, 2011, s. 20).

Pedagogika (społeczna) tworząc współczesną wizję dziecka i dzieciństwa skorzystała $z$ dorobku nauk humanistycznych i społecznych przyjmując orientację humanistyczną. Z jej założeń wynika, że dzieciństwo jest warto- 
ścią, a dziecko - osobą obdarzoną godnością i wolnością, jest podmiotem własnego rozwoju, któremu przypisuje się określone prawa. „We współczesnych koncepcjach pedagogicznych dziecko traktowane jest jako podmiot, współtwórca własnego dzieciństwa i społeczeństwa, natomiast dzieciństwo jako istotny etap przygotowujący do dorosłości” (Brągiel i in., 2019, s. 8). Określa się go także jako etap indywidualny w rozwoju człowieka i autonomiczny w rozwoju człowieka.

Nowy pedagogiczny dyskurs o dziecku i dzieciństwie wykorzystujący dorobek innych nauk (interdyscyplinarność w podejściu pedagogicznym) stawia dziecko w centrum zainteresowań, zawsze jednak w kontekście środowiskowych uwarunkowań jego rozwoju, wychowania, socjalizacji i edukacji, a także zmian, jakie zachodzą w skali lokalnej i globalnej.

$\mathrm{Na}$ współczesną wizję dziecka i dzieciństwa na gruncie pedagogiki społecznej zaważyło opisanie tych kategorii przez Barbarę Smolińską-Theiss, która wyróżniła węższe i szersze rozumienie dzieciństwa (Smolińska-Theiss, 1993, s. 11). Węższe ujęcie odnosi się do indywidualnego dziecięcego świata doświadczeń, znaczeń i wartości, które wiąże się z rodziną, grupą rówieśniczą, z instytucjami społecznymi oraz zjawiskami i procesami, jakie dziecko usiłuje zdefiniować, poznać, zrozumieć (dziecko jako osoba wolna, autonomiczna, której przynależy się szacunek i poszanowanie jej praw, podmiotowe traktowanie). Drugie, szersze ujęcie określa dzieciństwo w kontekście jego społeczno-kulturowych uwarunkowań - opisywana jest tutaj sytuacja dzieci w różnego typu środowiskach wychowawczych, głównie w rodzinie, jako prymarnym środowisku życia dziecka (najczęściej ujęcie przedmiotowe, chociaż w badaniach tego typu wykorzystywane jest także podejście łączone tj. przedmiotowo-podmiotowe).

Reasumując, współczesna wizja dziecka i dzieciństwa w naukach pedagogicznych (naukach o wychowaniu, edukacji) oraz prowadzonych na ich gruncie dyskursach to ujmowanie dziecka jako osoby wraz z przysługującymi jej atrybutami takimi jak: godność i niepowtarzalność każdego dziecka oraz wynikające z nich podmiotowe traktowanie, dziecko jako wartość sama w sobie (wartość autoteliczna), szacunek dla każdego dziecka, uznawanie jego praw. Należy także podkreślić, że dziecko, także dzieciństwo, ujmowane jest w pedagogice holistycznie, co oznacza, że uznawane jest ono jako integralna całość, psychofizyczna jedność. Integralność osoby wynika z faktu, że człowiek jest całością - spójną, kompletną i, jak podkreśla Franciszek Adamski, wartością najwyższą w świecie bytów stworzonych i wolną (Adamski, 2013, s. 112). 
Ważne dla wizji dziecka i dzieciństwa w pedagogice jest uznanie, że okres dzieciństwa (od 0 do 18 roku życia) stanowi pierwszy etap życia/biografii człowieka wprowadzający go w dorosłość. Pedagogika społeczna określa dzieciństwo jako kategorię społeczno-kulturową, co wynika z faktu, że jest ono społecznie i kulturowo konstruowane w danym czasie i przestrzeni. Opisana powyżej wizja dziecka i dzieciństwa znajduje odzwierciedlenie w poniższych rozważaniach Jadwigi Izdebskiej. Dowodzi ona, że

dzieciństwo to nie tylko pierwszy okres czy etap w życiu każdego człowieka, określona faza rozwoju intelektualnego, fizycznego, społecznego, emocjonalnego, ale należy go przede wszystkim rozumieć jako świat dziecka, świat jego przeżyć, doświadczeń, aktywności, zachowań, relacje z innymi osobami, skutki tych relacji, których źródłem są warunki jego egzystencji (materialne i niematerialne), środowisko życia, a więc rodzina, grupa rówieśnicza, kościół, kultura, zwłaszcza telewizja, inne media elektroniczne, codzienność (Izdebska, 2005, s. 203).

Zainteresowanie dzieckiem i dzieciństwem („,cywilizacja dziecka i dzieciństwa") wyznaczyło w pedagogice kierunki badań w tym obszarze. Rozważania teoretyczne wyznaczają paradygmat do projektowania badań nad dzieciństwem w różnych jego wymiarach i aspektach. Definiują kluczowe pojęcia pedagogiczne.

\section{Pedagogika personalistyczna a wizja dziecka i dzieciństwa}

Przedstawienie założeń pedagogiki personalistycznej oraz wizji dziecka i dzieciństwa w jej ujęciu należy rozpocząć od wyjaśnienia pojęcia personalizm. Wywodzi się ono z łacińskiego słowa persona i oznacza nurt filozoficzno-społeczny tworzący ontologiczno-społeczną koncepcję człowieka jako osoby, stanowiącej byt w sobie i dla siebie (Adamski, 2005, s. 349). Z tak przedstawionym rozumieniem personalizmu utożsamia się autorka artykułu.

W literaturze filozoficznej i teologicznej wyróżnia się wiele odmian personalizmu podkreślając jednocześnie, że każdy z nich uznaje człowieka i jego byt osobowy jako fundament ludzkiej egzystencji.

Jednym $\mathrm{z}$ autorów, który podjął problematykę personalizmu i jego odmian jest Czesław Bartnik, który wyróżnił: 
- personalizm fenomenologiczny i historyczny (M. Scheler, R. Ingarden, R. Guardini);

- personalizm egzystencjalistyczny (G. Marcel, K. Jaspers, P. Tillich, D.C. Macintosh);

- personalizm neotomistyczny (J. Maritain, J. Woroniecki, W. Granat, M. Gogacz, M. A. Krąpiec);

- personalizm filozoficzno-religijny (F. Ebner, M. Buber, P. Teilhard de Chardin);

- personalizm absolutystyczny (E. Caird, J. Royce, M. W. Calkins, W. E. Hocking)

- personalizm panpsychistyczny (W. Stern, A. N. Whitehead, Ch. Hartshorne) (Bartnik, 2000, s. 128-129).

W wyróżnionym powyżej podziale personalizmów - nie wnikając w ich szczegółowe charakterystyki - podstawowym kluczem interpretacyjnym ich analiz jest osobowa struktura człowieka i jego osobowe istnienie. Warto dodać, że osoba interpretowana była w poszczególnych personalizmach jako autonomiczny podmiot, nie zaś „,produkt” procesów społecznych czy stosunków interpersonalnych.

$\mathrm{Na}$ gruncie polskim personalizm jako nurt filozoficzno-społeczny ma swoją specyfikę. I tak np. w ujęciu Barbary Kiereś stanowi główną tradycję myślową, która sięga do Ewangelii, przenikając całą polską mentalność we wszystkich dziedzinach życia i nauki (Kiereś, 2016, s. 273). Typowe cechy tak ujmowanego personalizmu to: przekonanie o nieskończonej godności człowieka, o jego transcendencji do świata przyrody oraz jego wolności osobistej, a także społecznej. Wyróżnione cechy/założenia wydają się być kluczowe także do uprawiania pedagogiki.

Dla pedagogiki jako nauki o wychowaniu człowieka wydaje się być przydatny podział personalizmu autorstwa Ignacego Deca, który wyróżnił jego trzy rodzaje:

1) personalizm horyzontalny (ateistyczny) - jest to humanizm, w którym pomijany jest duchowy wymiar człowieka

2) personalizm wertykalny (teistyczny) - pozatomistyczny, który dzieli się na:

a) personalizm moralno-społeczny (E. Mounier)

b) personalizm fenomenologiczno-aksjologiczny (M. Scheler, R. Ingarden)

c) personalizm egzystencjalistyczny - dialogiczny (K. Jaspers, G. Marcel) oraz

d) personalizm ewolucyjno-kosmiczny (P. Teilhard de Chardin), a także 
3) personalizm klasyczny - tomistyczny o orientacji metafizycznej, który nawiązuje do klasycznej antropologii Greków wzbogaconej przez Objawienie Chrześcijańskie, a następnie kontynuowane i rozwijane przez filozoficzno-teologiczną myśl średniowieczną (Tomasz z Akwinu) (za: Kiereś, 2016, s. 273-274).

Dwa pierwsze rodzaje personalizmów uwzględniają w strukturze bytu ludzkiego element duchowy i transcendencję człowieka wobec świata przyrody. Ujmują przy tym takie ważne wymiary życia człowieka jak: przyrodniczy, etyczny, społeczny, pomijając niestety wymiar metafizyczny - to co stanowi o jego proposium humanum (tamże, s. 274). Natomiast personalizm klasyczny - teistyczny i różne jego odmiany - posiadają wspólny „rdzeń”: jest nim rozumienie człowieka jako bytu osobowego. Różnice dotyczące różnych odmian personalizmu klasycznego dotyczą tego, co stanowi właściwości bytu osobowego (Kiereś, 2016, s. 275). Można jednak powiedzieć, że personalizmy te się dopełniają.

W opinii Ignacego Deca - twórcy przedstawionej powyżej klasyfikacji personalizmu na trzy jego rodzaje - zasadne w opisywaniu człowieka, tego kim on jest rzeczywiście, jest wykorzystanie personalizmu klasycznego: teistyczno-tomistycznego, ponieważ wyrasta on z realizmu poznawczego (za: Kiereś, 2016, s. 274). Zasadne wydaje się być więc ujmowanie personalizmu chrześcijańskiego (klasycznego) jako uniwersalnego paradygmatu opisywania człowieka, który powinien być wykorzystywany na gruncie nauk humanistycznych i społecznych. Pisał na ten temat m. in. Stefan Kunowski: ,z reguły kierunki personalizmu przedstawiają człowieka tylko częściowo i jednostronnie, a swoje zasady rozciągają w zasadzie na pewne grupy społeczne, jedynie personalizm chrześcijański z racji swego uniwersalizmu obejmuje całego człowieka i odnosi się do wszystkich ludzi" (Kunowski, 2000, s. 63).

Personalizm wywodzi się z tradycji greckiej, później ubogaconej przez kulturę chrześcijańską, a szczególnie przez jej filozoficzno-teologiczną myśl. Określają go dwa odrębne podejścia, uzupełniające się - teologiczne i filozoficzne (Kiereś, 2010, s. 94-95). Na ich kanwie tworzyła się pedagogika chrześcijańska (podejście teologiczne) oraz pedagogika personalistyczna (podejście filozoficzne). Ich wspólną cechą jest ujmowanie człowieka jako osoby; w pierwszym przypadku osoba ma wymiar teologiczny (związek człowieka z Bogiem), w drugim wskazuje się na życie rozumne (możność i aktualizacja) (tamże, s. 100). Autorka artykułu przyjmuje punkt widzenia Barbary Kiereś dotyczący rozumienia i charakterystyki pedagogiki personalistycznej. Uważa - podobnie jak cytowana autorka - że tak ujmowana pe- 
dagogika personalistyczna dotyczy każdego człowieka, niezależnie od tego, czy jest chrześcijaninem, czy nim nie jest. Opisując konkretnego człowieka w praktyce (dziecko w procesie wychowania), nie da się oddzielić wyróżnionych perspektyw tj. teologicznej i filozoficznej. Wynika to z faktu osobowego podejścia do człowieka (dziecka) jako osoby, które powinno być całościowe (kompletne). Obydwa podejścia możemy rozpatrywać jedynie pojęciowo (myślowo).

Dla pedagogiki wizja dziecka i dzieciństwa wynikająca z założeń pedagogiki personalistycznej tworzy nie tylko podstawy teoretyczne, naukowe wszelkich badań (ich paradygmat), ale jest także bardzo ważna dla konstruowania badań empirycznych dotyczących dzieciństwa w jego różnych wymiarach.

Konkludując, pedagogika personalistyczna jako jeden z kierunków pedagogiki współczesnej wywodzi się z filozofii personalistycznej - personalizmu filozoficznego. Personalizm tworzy koncepcję człowieka jako osoby autonomicznej wartości charakteryzującej się wolnością, zdolnej do rozumnego kierowania własnym losem, a także zdolnej do poznawania prawdy i wrażliwej na zło (Tyluś, 2014, s. 65).

Można powiedzieć, że pojęcie osoby jest podstawową kategorią pedagogiki personalistycznej, jej wyznacznikiem. Takie podejście do pedagogiki personalistycznej i kategorii osoby znajduje się w Leksykonie PWN. Pedagogika, gdzie czytamy, że „[p]odstawowym wyznacznikiem personalizmu jest twierdzenie, że człowiek - zanim zostaną mu przypisane jakieś nazwy, cechy bądź właściwości - jest osobą; bycie osobą stanowiące fakt pierwotny i nieredukowalny, ma charakter etyczny - do pojęcia osoby przynależą bowiem wolność, szacunek, równość, tolerancja, ale także i odpowiedzialność" (Milerski i Śliwerski, 2000, s. 155).

Pedagogika personalistyczna, nawiązując do personalizmu filozoficznego, przedstawia wizję człowieka jako osoby. Franciszek Adamski podkreśla, że personalizm (filozoficzny) tworzy ontologiczno-aksjologiczną koncepcję człowieka jako osoby stanowiącej byt w sobie i dla siebie; będąc częścią świata materialnego przerasta go swym nadprzyrodzonym odniesieniem. W swoich rozważaniach dotyczących personalizmu i pedagogiki personalistycznej dowodzi, że

osoba ludzka będąc częścią całego kosmosu - świata materialnego, przerasta go jednocześnie swym nadprzyrodzonym odniesieniem, jest obdarzona przysługującymi jej z natury prawami i jako taka stanowi cząstkę składową wielorakich społeczności [...] Będąc osobą, człowiek żyje w świecie rzeczywistych 
przedmiotów, ale sam jest podmiotem, przerastającym otaczającą go rzeczywistość szczególnym wyniesieniem w hierarchii bytów stworzonych (Adamski, 2005, s. 349-350).

W przedstawionej powyżej definicji osoby ludzkiej jako podstawowej kategorii w personalizmie autor wskazuje na personalizm chrześcijański jako podstawę pedagogiki personalistycznej i człowieka jako osoby. Zarówno Franciszek Adamski jak i Stefan Kunowski zgadzają się, że personalizm chrześcijański jest uniwersalny i przydatny dla pedagogiki jako nauki o wychowaniu człowieka (wszystkich jej subdyscyplin) (Kunowski, 2000, s. 63). Pedagogika personalistyczna o inspiracji chrześcijańskiej eksponuje osobę ludzką jako podmiot zaangażowany $\mathrm{w}$ proces socjalizacji, kształcenia i wychowania, gdzie afirmuje się godność, rozumność, wolność, zdolność do miłości każdej osoby, każdy bowiem podmiot osobowy posiada w sobie walor niepowtarzalny i nadrzędny wobec wszystkich wartości materialnych, ekonomicznych i społeczno-politycznych (Nowak, 1996, s. 31-51).

Osobę ludzką jako pojęcie kluczowe dla personalizmu (także pedagogiki personalistycznej), przedstawił Wincenty Granat, który napisał: „Osoba ludzka to jednostkowy, indywidualny, substancjalny, cielesno-duchowy podmiot zdolny działać w sposób rozumny, dobrowolny, moralny i społeczny w celu harmonijnego ubogacenia siebie i innych ludzi w zakresie kultury" (Granat, 1985, s. 68).

W prezentowanym ujęciu podkreśla się duchowy wymiar człowieka, jego odniesienie do Boga osobowego. Bardzo ważne jest w tym ujęciu uwzględnienie w strukturze bytu ludzkiego elementu duchowego i transcendencji człowieka wobec świata przyrody. Człowiek ujmowany jest tutaj wielowymiarowo, istotna jest tu jego integralność jako osoby w jej wymiarze materialnym i duchowym.

Z założeń pedagogiki personalistycznej inspirowanej personalizmem chrześcijańskim wynika, że wizja dziecka i dzieciństwa powiązana jest z koncepcją człowieka, świata i życia oraz spojrzenia na podstawowe wartości, jakie są tutaj formułowane. Podobne stanowisko reprezentuje Katarzyna Segiet. Jej rozważania potwierdzają, że do poznania wizji dziecka i dzieciństwa na gruncie pedagogiki współczesnej niezbędne jest odniesienie do filozofii, zwłaszcza filozofii chrześcijańskiej i jej podstawowego nurtu, tj. personalizmu chrześcijańskiego tworzącego antropologiczne podstawy wychowania (Segiet, 2011, s. 37). Odwołując się do Władysława Szewczyka przytoczyła następujące założenia wskazujące na personalistyczne spojrzenie na człowieka, które implikuje spojrzenie na dziecko: 
dziecko jest osobą, ma nieocenioną wartość (afirmacja); dziecko jest osobą, uznajemy w nim prymat ducha (prymat); dziecko jest osobą, czyli nie może być urzeczowione (traktowane jako przedmiot, instrumentalnie); dziecko jest osobą i ma niezbywalne prawa, które tkwią w naturze ludzkiej (podmiot); dziecko jest osobą i oczekuje powinności od osób opiekujących się nim (zobowiązania); dziecko jest osobą, jego dobro zawsze niszczy totalitaryzm i liberalizm (Szewczyk, 1998, s. 169).

Osoba/dziecko posiada w myśl założeń pedagogiki personalistycznej przyrodzoną mu godność, niepowtarzalność, wolność. „Jest także bytem relacyjnym, otwartym na więzi z innymi osobami ludzkimi i osobowym Bogiem" (Wierzbicki, 2016, s. 697). Pedagogika personalistyczna „łączy w wspólnej syntezie ideał miłości bliźniego i miłości siebie jako dwóch wektorów odpowiedzi na wartość osoby" (tamże, s. 697).

Koncepcja człowieka jako osoby (personalizm, głównie personalizm chrześcijański) implikuje wizję dziecka i dzieciństwa. Pozwala odpowiedzieć na podstawowe pytania: kim jest człowiek?, a więc i dziecko, czym jest dzieciństwo i jak należy ujmować odbywający się w tym okresie proces wychowania? Odpowiedzi na te pytania są istotne dla pedagogiki w jej wymiarze teoretycznym i praktycznym. Oba te aspekty znajdują odzwierciedlenie w publikacjach Karola Wojtyły, który napisał: „,personalizm oznacza nie tyle jakąś teorię osoby czy też teoretyczną naukę o osobie. Posiada on znaczenie w dużej mierze praktyczne i etyczne - chodzi o osobę jako podmiot i przedmiot działania, jako podmiot uprawnień" (Wojtyła, 1961, s. 64).

Osoba w ujęciu Jana Pawła II jest przedmiotem i podmiotem oraz celem życia społecznego, na pierwszym miejscu stawiał osobę i jej integralny rozwój (Sztaba, 2011, s. 349), co bezpośrednio łączy się z wychowaniem człowieka jako osoby ludzkiej (pedagogika).

We wszystkich przytoczonych charakterystykach pedagogiki personalistycznej wskazuje się na podstawowy jej wyznacznik, którym jest uznanie człowieka jako osoby ludzkiej wraz z przypisanymi jej cechami bądź właściwościami. „Bycie osobą stanowi fakt pierwotny i nieredukowalny, warunek sine qua non uprawiania jakiejkolwiek humanistyki" (Chrost, 2013, s. 49). W jej genezie, co podkreślił w swoich rozważaniach cytowany powyżej autor, należy sięgnąć do grecko-rzymskiej tradycji filozoficznej (kultura chrześcijańska).

Franciszek Adamski charakteryzując pedagogikę personalistyczną dodaje, że „opiera się ona na założeniu głoszącym, że podmiotem wychowania jest osoba ludzka, a zatem i dziecko (człowiek w okresie dzieciństwa), któ- 
re znajduje się w pierwszym etapie rozwoju osobniczego" (Adamski, 1999, s. 75). Personalistyczną koncepcję człowieka-osoby posiadającej wartość ontologiczną (in se) tworzą następujące założenia, wskazujące, że:

- jest osobą - także zanim jest w stanie uzyskać pełnię swej autonomii (tę wartość posiada od momentu poczęcia w łonie matki),

- posiada swą godność i wartość - nie otrzymując ich od innych ludzi,

- osoba ludzka jest wartością najwyższą, bezwzględną - w świecie bytów stworzonych jest jedyną rzeczywistością posiadającą wartość per se,

- $\quad$ z tej przyczyny - będąc osobą per se, tj. mającą własny cel, którym jest doskonalenie się w swym istnieniu - nie może być traktowany jako środek do celu innego człowieka względem społeczeństwa (tamże, s. 76).

Pedagogika jest nauką o wychowaniu człowieka, a zatem koncepcja/wizja człowieka/dziecka stanowi podstawę jego procesu wychowania. W myśl założeń pedagogiki personalistycznej dziecku jako osobie przypisana jest wartość oraz godność osoby ludzkiej. Wartość osoby określana jest w pedagogice pojęciem ,autonomii ludzkiej”. Dziecko jest więc tutaj traktowane jako podmiot wychowania, wartość autonomiczna, osoba, której należy się szacunek. Podkreśla się także, że wychowanie dziecka opiera się na relacyjności z drugim człowiekiem: rodzicem, nauczycielem, wychowawcą, wskazując jednocześnie na dialog jako ważne „narzędzie” w wychowaniu, w doskonaleniu się wychowanka jako człowieka. Takie ujęcie pedagogiki/ /wychowania reprezentuje m.in. Marian Nowak, który stwierdza, że wychowanie w pedagogice personalistycznej ma przede wszystkim charakter spotkania osób, którym przysługuje taka sama godność. Spotkanie to dokonuje się w konkretnej rzeczywistości, zaś zadaniem pedagogiki personalistycznej jest ujawnienie podstawowego sensu wychowania w konkretnych uwarunkowaniach historycznych, społecznych, politycznych i kulturowych (Nowak, 1998, s. 29-42).

Dziecko i dzieciństwo ujmowane jest także w pedagogice personalistycznej w kategoriach „wolnościowych”. „Wolność osoby urasta do rangi zasady o charakterze podwaliny całego porządku społeczno-moralnego" (Adamski, 2005, s. 351). Należy ją tutaj rozumieć jako autonomię osoby, a więc jej prawo do własnej, wybranej przez siebie drogi samorealizacji w konkretnej rzeczywistości życia społecznego, w której nie może być traktowana jako środek do celu dla innej osoby ani dla społeczeństwa.

Ważnym założeniem pedagogiki personalistycznej jest także dobro człowieka/dziecka (cel wychowania), zawsze jednak w odniesieniu do dobra wspól- 
nego. Dlatego godność i wolność osoby przeciwstawiane są tutaj jakiemukolwiek sterowaniu jej wychowaniem, manipulowaniu treściami kształcenia i wychowania, jego zinstrumentalizowaniu czy zmonopolizowaniu - co nie oznacza, że wychowanie nie powinno być kierowane. Wręcz przeciwnie, powinno być skierowane na wartości i chronione przed treściami oraz sytuacjami stanowiącymi antywartości (tamże, s. 351). Aby było pełne, powinno uwzględniać wszystkie środowiska wychowawcze: rodzinę, szkołę, środowisko lokalne i globalne, mass media.

Dziecko traktowane jest $\mathrm{w}$ pedagogice personalistycznej integralnie, tzn. że wszystkie sfery jego rozwoju: intelektualną, psychiczną, fizyczną, społeczno-kulturalną oraz duchową należy traktować jako integralne części pewnej całości, ponieważ człowiek/osoba to psychofizyczna jedność, rozwijająca się, doskonaląca się (w dobru, ku dobru) w drodze wychowania i samowychowania. Integralność osoby oznacza, że człowiek jest całością - spójną, kompletną. Barbara Kiereś dodaje: „W wychowaniu chodzi o wytworzenie sprawności pozytywnych, czyli cnót, które należy zaszczepiać w człowieku, oraz o eliminowanie ujemnych, czyli wad - należy je wykorzeniać” (Kiereś, 2010, s. 97). Wychowanie jest zatem - posługując się określeniem cytowanej autorki - usprawnianiem całego człowieka, obejmuje jego wolę, umysł, sferę życia popędowego i uczuciowego, w pewnej mierze także jego wewnętrzne i zewnętrzne zmysły (pamięć, uwaga, wyobraźnia, a także ciało) (Kiereś, 2015, s. 85-109).

$\mathrm{W}$ pedagogice personalistycznej kluczową rolę $\mathrm{w}$ procesie wychowania i samowychowania przypisuje się świadomości celu, która nadaje owym procesom sens. Podstawowym zadaniem wychowawców jest zatem usprawnianie wychowanka w stałym dążeniu do celu (sensu wychowania), także celu ostatecznego, tj. urzeczywistnienia się pełni doskonałości każdego człowieka. Wychowawca to osoba, która ma w tym dążeniu do celu - doskonaleniu się - pomóc. Nie zastępuje on aktywności wychowanka, ale ją stymuluje: „oferując stosowne treści kulturowe w takiej mierze i w takim stopniu, aby odpowiedzieć na potrzeby wychowanka, które się wyrażają w jego zadatkach, uzdolnieniach - potencjalnościach podmiotu wychowania" (Adamski, 1999, s. 77).

Należy zaznaczyć, że kultura pełni rolę środka, a nie celu wychowania celem jest osiąganie możliwie najwyższego stopnia rozwoju osobowego podmiotu. Wychowankowi przypisuje się w tym procesie rozwoju osobowego stosunek aktywny, musi tak ,przepracowywać” wartości proponowane przez wychowawców (,zanurzone” w wartościach kulturowych, społecznych), aby stały się jego własnością (internalizacja), wzbogacały go wewnętrznie, czy- 
niły go zdolnym do wyboru i jego współtworzenia. Jak dowodzi Franciszek Adamski, wychowanie personalistyczne jest wychowaniem do wolności wyboru dobra. Wolność należy tutaj rozumieć jako zdolność wyboru dobra i jego realizacji - ustawicznego poszukiwania tego, co zostało poznane i uznane jako godne naszego dążenia, albowiem stanowi środek naszego doskonalenia osobowego (tamże, s. 77). Podstawową tezą wychowania personalistycznego jest uznanie, że wychowanie służy przede wszystkim człowiekowi - ludzkiej osobie, ale służy też społeczeństwu. Personalizm podkreśla, że oprócz wartości w wymiarze indywidualnym, ważne są także wartości wspólnotowe. Obowiązkiem człowieka jest realizować cele społeczne, społeczność natomiast powinna mu pomagać w realizacji jego osobistych celów i zadań. Osoba ma prawo - w myśl założeń pedagogiki personalistycznej do własnej, wybranej przez siebie drogi samorealizacji w konkretnej rzeczywistości życia społecznego, w której nie może być traktowana jako środek do celu innej osoby ani dla społeczeństwa.

W pedagogice personalistycznej podkreślane jest znaczenie rodziny jako podstawowego środowiska życia dziecka, jego dzieciństwa. Wskazuje się na prawo rodziców do wychowania, które traktowane jest jako prawo naturalne, a zatem przysługujące $\mathrm{z}$ natury rzeczy rodzicom, wskazując jednocześnie na ich odpowiedzialność za dziecko i jego prawidłowy rozwój z uwzględnieniem wszystkich własności/cech dziecka jako osoby (godność, wolność, autonomia, prawa, szacunek).

Reasumując, założenia pedagogiki personalistycznej odnoszące się do wychowania można przedstawić syntetycznie w postaci poniższych założeń:

- wychowanie jest tutaj rozumiane jako ważny czynnik promowania wszechstronnie pojmowanego dobra osoby (dziecka),

- jednym z celów wychowania jest uzdalnianie osoby/dziecka do przyjęcia kierownictwa nad własnym procesem rozwoju,

- wychowanie powinno prowadzić do tego, aby wychowanek uświadomił sobie w pełni fakt bycia osobą,

- proces wychowania spoczywa przede wszystkim w rękach wychowanka, wychowawca odgrywa rolę pomocniczą,

- podkreśla się związek między nauczaniem a wychowaniem,

- podkreśla się nadrzędność i wartość wychowawczej funkcji rodziny,

- przypomina się o wpływie czynnika nadprzyrodzonego (wiara i łaska w wychowaniu),

- ostrzega się przed niebezpieczeństwami płynącymi z naturalizmu, indywidualizmu czy liberalizmu (Nowak, 1998, s. 29-42; Chrost, 2013, s. 56). 
W niniejszych rozważaniach przyjęto istotę pedagogiki personalistycznej za Marianem Nowakiem, który scharakteryzował ją w następujących słowach:

Pedagogika personalistyczna jest jednych z ważnych nurtów współczesnej refleksji pedagogicznej. Płaszczyznę odniesienia dla tego kierunku stanowi koncepcja świata i człowieka, która przyjmuje wzajemną zależność od siebie takich elementów, jak względny indeterminizm, wolność, transcendencja. Na płaszczyźnie epistemologicznej pedagogika personalistyczna jawi się jako koncepcja wychowania oparta na teorii poznania, rozważającej różne stopnie poznania przy przyjęciu, jako zasady, podstawowej jednorodności poznania ludzkiego, zdolnego dociekać prawdy. Refleksja teoretyczna w pedagogice personalistycznej widzi jako szczególne zadanie stanowienie czegoś w rodzaju świadomości krytycznej w odniesieniu do pedagogiki i do wychowania (Nowak, 2006, s. 246).

Można zatem powiedzieć, że wizja dziecka i dzieciństwa w ujęciu pedagogiki personalistycznej wynika z koncepcji człowieka jako osoby ludzkiej i jego cech. Stanowi ona podstawę teoretyczną do projektowania badań nad dzieciństwem w pedagogice (w sensie ogólnym), także w pedagogice społecznej zajmującej się głównie społeczno-kulturowymi, środowiskowymi uwarunkowaniami dzieciństwa.

\section{Podsumowanie}

Pedagogika jest nauką o wychowaniu człowieka/dziecka, które należy rozumieć jako proces wspierania jego rozwoju osobowego. Człowieka jako osobę definiuje pedagogika personalistyczna, jej źródłem jest personalizm, który Marian Nowak określa jako doktrynę podkreślającą autonomiczną wartość człowieka jako osoby, programy działań wspierające rozwój osoby ludzkiej, a także podporządkowanie wartości ekonomicznych wartościom osobowo-duchowym (Nowak, 2008, s. 542).

Z założeń pedagogiki personalistycznej wyłania się konkretna wizja osoby/dziecka, jego wychowania w okresie dzieciństwa. Wskazuje ona na podmiotowe, a tym samym osobowe traktowanie dziecka, pomoc dziecku (rodzice, nauczyciele, wychowawcy) w jego rozwoju, samodoskonaleniu się w „człowieczeństwie”. Realizacji wymienionych założeń powinien służyć okres dzieciństwa - stworzenie dziecku warunków wszechstronnego i integralnego rozwoju. 
Dziecko (i dzieciństwo) traktowane jest na gruncie pedagogiki personalistycznej także jako podmiot własnego rozwoju. Ważna w procesie rozwoju jest aktywność dziecka przejawiająca się w jego zaangażowaniu w planowanie własnego życia, edukacji (autonomia dziecka, wolność), etc. Takie podejście do dziecka i dzieciństwa widoczne jest we współczesnych badaniach pedagogicznych, w tym badaniach nad dzieciństwem w pedagogice społecznej. Podkreśla się w nich podmiotowość dziecka, jego wartość jako osoby, godność, przysługujące mu prawa, własną aktywność sprawczą dotyczącą swojego rozwoju, nabywania kompetencji społecznych (Bragiel i in., 2019, s. 26). Warto wspomnieć tutaj np. o badaniach Ewy Jarosz (2008), Barbary Smolińskiej-Theiss (2014) czy Pauliny Formy (2016).

Ponadto dziecko i jego dzieciństwo w pedagogice społecznej jest traktowane - podobnie jak w założeniach pedagogiki personalistycznej - holistycznie/integralnie (całościowe ujęcie dziecka), zarówno w aspekcie wewnętrznym (osobowość dziecka, jego potrzeby, zainteresowania, motywy), jak i zewnętrznym (różnego typu wpływy środowiskowe ujmowane całościowo). Podkreśla się tutaj, że integralne podejście do dziecka w procesie wychowania pozwala mu stawać się człowiekiem - całością spójną i kompletną. Badania dotyczące dziecka i jego dzieciństwa ujmowanego integralnie w procesie wychowania prowadzą m. in. Katarzyna Segiet (2011) oraz Bożena Matyjas $(2012,2017)$.

Pedagogika personalistyczna przedstawia pełną koncepcję człowieka, która oparta jest na greckiej paidei, ale przede wszystkim nawiązuje do judeochrześcijańskiej wizji człowieczeństwa. Pomaga ona współczesnemu wychowawcy ocenić różne propozycje kulturowe pod kątem rzeczywistego dobra dla człowieka, uczy kierować się w życiu pewną hierarchią dóbr, daje do ręki drogowskaz (Kiereś, 2010, s. 101). Jest to także istotne założenie dla badaczy dziecka i dzieciństwa, którzy powinni w swoich projektach badań empirycznych kierować się przede wszystkim dobrem dziecka.

Konkludując, można stwierdzić, że pedagogika personalistyczna jako jeden z najbardziej znaczących kierunków współczesnej pedagogiki jako nauki o wychowaniu człowieka jest bardzo przydatna dla pedagogów, ponieważ odpowiada na pytanie, kim jest człowiek/dziecko, jak należy go/je wychowywać, komu przypisuje się w tym procesie rolę nadrzędną. Przedstawia ponadczasową, uniwersalną i potrzebną dla współczesnej pedagogiki koncepcję człowieka jako osoby (Adamski, 1999, s. 75). Wizja dziecka i jego dzieciństwa wynikająca $\mathrm{z}$ tej koncepcji wykorzystywana jest w badaniach pedagogicznych, zwłaszcza na gruncie pedagogiki ogólnej (teoria wychowania - teoretyczne podstawy badań empirycznych) oraz pedagogiki 
społecznej (środowiskowe, społeczno-kulturowe uwarunkowania wychowania). To właśnie w pedagogice społecznej podkreśla się społeczno-kulturowy kontekst badań nad dzieciństwem. Jako przykład mogą służyć badania Jadwigi Izdebskiej (2006), Barbary Smolińskiej-Theiss (2014) czy Bożeny Matyjas (2003, 2012, 2017), które uwzględniają w procesie wychowania dziecka różne środowiska wychowawcze (małe i duże miasto, wieś) oraz różne uwarunkowania statusowe, rodzinne tego procesu (np. rodzina wiejska, miejska, bezrobotna).

Na zakończenie rozważań dotyczących wizji dziecka i dzieciństwa w pedagogice personalistycznej należy dodać, że wizja ta jest zbieżna (w warstwie założeń teoretycznych) z tą wykorzystywaną w pedagogice, zwłaszcza pedagogice społecznej, w zakresie ujmowania dziecka jako osoby i wynikającymi z tego faktu cechami. W badaniach pedagogiki społecznej nie jest jednak wyraźnie akcentowany wymiar transcendentny, duchowy dziecka jako osoby $-\mathrm{w}$ rozumieniu personalizmu chrześcijańskiego.

\section{Bibliografia}

Adamski, F. (1999). Poza kryzysem tożsamości w kierunku pedagogiki personalistycznej. W: J. Kostkiewicz (red.), Wprowadzenie do pedagogiki ogólnej (s. 73 - 78). Stalowa Wola: WNS KUL.

Adamski, F. (2005). Personalizm i pedagogika personalistyczna. W: T. Pilch (red.), Encyklopedia Pedagogiczna XXI wieku, t. 4 (s. 349-353). Warszawa: Wydawnictwo Akademickie Żak.

Adamski, F. (2013). Pedagogika chrześcijańska pedagogiką personalistyczną. Pedagogia Christiana, 31/1, 107-120.

Bartnik, C. S. (2000). Dogmatyka katolicka. Lublin: KUL.

Brągiel, J., Matyjas, B., Segiet, K. (2019). Dzieciństwo - w stronę poznania, zrozumienia i zmiany. Poznań: Wydawnictwo Naukowe UAM.

Chrost, S. (2013). Homo capax Dei jako ideat wychowania. Kraków: Impuls.

Forma, P. (2016). Dziecięca kreacja biografii w rodzinach wielodzietnych. Kraków: Impuls.

Godawa, G. (2017). Integralna wizja człowieka jako fundament kultury i wychowania. Analecta Cracoviensia, 49, 319-340.

Granat, W. (1985). Personalizm chrześcijański. Teologia osoby ludzkiej. Poznań: Towarzystwo Teologów Dogmatyków.

Izdebska, J. (2005). Dzieciństwo przed szklanym ekranem telewizora i kompute- 
ra - nowe jego oblicze. W: J. Izdebska, T. Sosnowski (red.), Dziecko $i$ media elektroniczne - nowy wymiar dzieciństwa. Białystok: Trans Humana.

Izdebska, J. (2006). Dom rodzinny postrzegany przez dzieci. W kontekście społeczno-kulturowych zróżnicowań współczesnej rodziny. Białystok: Trans Humana. Izdebska, J. (2016). Dzieciństwo. W: K. Chałas, A. Maj (red.), Encyklopedia aksjologii pedagogicznej (s. 305-315). Radom: Wydawnictwo POLWEN.

Jarosz, E. (2008). Ochrona dzieci przed krzywdzeniem. Perspektywa globalna i lokalna. Katowice: Wydawnictwo Uniwersytetu Śląskiego.

Jarosz, E. (2017). Dziecko i dzieciństwo - pejzaż współczesny. Rzecz o badaniach nad dzieciństwem. Pedagogika Społeczna, 64/2, 57-81.

Jarosz, E. (2018). Partycypacja społeczna dzieci - szkic z rozwoju interdyscyplinarnego dyskursu. W: M. Michalak (red.), Prawa dziecka wczoraj, dziś i jutro - perspektywa korczakowska, t. 2 (s. 285-303). Warszawa: Rzecznik Praw Dziecka

Kiereś, B. (2010). Podstawy antropologiczne pedagogiki personalistycznej. W: M. Nowak, P. Magier, J. Szewczak, (red.), Antropologiczna pedagogika ogólna (s. 95- 102). Lublin: Gaudium.

Kiereś, B. (2015). U podstaw pedagogiki personalistycznej. Filozoficzny kontekst sporu o wychowanie. Lublin: Polskie Towarzystwo Tomasza z Akwinu.

Kiereś, B. (2016). Personalizm w pedagogice. Polska Myśl Pedagogiczna, 2(2), 271-281 .

Kunowski, S. (2000). Problematyka wspótczesnych systemów wychowania. Kraków: Impuls.

Łopatka, A. (2000). Dziecko. Jego prawa człowieka. Warszawa: Wydawnictwo Prawnicze Iris.

Matyjas, B. (2003). Dzieciństwo w rodzinie bezrobotnych w środowisku matego miasta (na przykladzie Pińczowa). Kielce: Wydawnictwo Akademii Świętokrzyskiej.

Matyjas, B. (2008). Dzieciństwo w kryzysie. Etiologia zjawiska. Warszawa: Wydawnictwo Akademickie Żak.

Matyjas, B. (2012). Dzieciństwo na wsi. Warunki życia i edukacji. Kraków: Wydawnictwo Impuls.

Matyjas, B. (2017). Topos dzieciństwa wielkomiejskiego. Warunki socjalizacyjno-edukacyjne dzieci w wieku szkolnym. Warszawa: Difin.

Milerski, B., Śliwerski, B. (red.). (2000). Leksykon PWN. Pedagogika. Warszawa: PWN.

Nowak, M. (1996). O pedagogikę wrażliwą na osobę i wspólnoty osób. Roczniki Nauk Społecznych, 24 (2), 31-52. 
Nowak, M. (1998). Ku nowej edukacji zorientowanej na osobę. W: B. Śliwerski (red.), Pedagogika alternatywna - dylematy teorii i praktyki (s. 115-130). Kraków: Impuls.

Nowak, M. (1999). Podstawy pedagogiki otwartej. Lublin: KUL.

Nowak, M. (2006). Pedagogika personalistyczna. W: Z. Kwieciński, B. Śliwerski (red.). Pedagogika. Podręcznik akademicki, t. 1 (s. 232-247). Warszawa: PWN. Nowak, M. (2008). Teorie i koncepcje wychowania. Warszawa: WAiP

Segiet, K. (2000). Dziecko w wielkim mieście. Poznań: Oficyna Wydawnicza G\& P. Segiet, K. (2007). Wizja dziecka jako osoby (refleksja antropologiczna i teologiczna). W: K. Segiet (red.), Dziecko i dzieciństwo. W kręgu pytań i poszukiwań teoretyczno-badawczych. Poznań: Książka i Wiedza.

Segiet, K. (2010). Dziecko i dzieciństwo jako wartość. Chowanna, 34/1, 129-137.

Segiet, K. (2011). Dziecko i jego dzieciństwo w perspektywie naukowego poznania i doświadczania rzeczywistości. Studium pedagogiczno-społeczne. Poznań: Wydawnictwo Naukowe UAM.

Smolińska-Theiss, B. (1993). Dzieciństwo w matym mieście. Warszawa: Wydawnictwo UW.

Smolińska-Theiss, B. (1995). Trzy nurty badań nad dzieciństwem. Problemy Opiekuńczo-Wychowawcze, 10.

Smolińska-Theiss, B. (2010). Rozwój badań nad dzieciństwem. Chowanna, 34/1, $13-26$.

Smolińska-Theiss, B. (2014). Dzieciństwo jako status społeczny. Edukacyjne przywileje dzieci klasy średniej. Warszawa: Wydawnictwo APS.

Starnawski, W. (2014). Dwa sposoby uprawiania filozofii w wychowaniu. Seminare, 35(1), 81-87.

Szczepska-Pustkowska, M. (2009). Kategoria dziecka i dzieciństwa w nowożytnej myśli pedagogicznej. W: D. Klus-Stańska, M. Szczepska-Pustkowska (red.). Pedagogika wczesnoszkolna - dyskursy, problemy, rozwiazania (s. 79-122). Warszawa: WAiP.

Szczepska-Pustkowska, M. (2011). Od filozofii dzieciństwa do dziecięcej filozofii życia. Casus władzy (i demokracji). Kraków: Impuls.

Szczepska-Pustkowska, M. (2012). W stronę filozofii dzieciństwa. Adultystyczna wizja dziecka i dzieciństwa z Arystotelesem w tle. Przegląd Pedagogiczny, 21(1), $35-49$.

Szewczyk, W. (1998). Kim jest człowiek. Zarys antropologii filozoficznej. Tarnów: BIBLOS.

Sztaba, M. (2011). Troska bt. Jana Pawła II o etyczno-moralne podstawy życia spotecznego. Tyniec: Wydawnictwo Benedyktynów.

Śliwerski, B. (2007). Pedagogika dziecka. Gdańsk: GWP. 
Śliwerski, B. (2012). Wspótczesne teorie i nurty wychowania. Kraków: Impuls.

Tyluś, U. (2014). Wprowadzenie do studiowania pedagogiki. Siedlce: Wydawnictwo Uniwersytetu Przyrodniczo-Humanistycznego.

Wierzbicki, A. (2016). Osoba. W: K. Chałas, A. Maj (red.), Encyklopedia aksjologii pedagogicznej (s. 694-697). Radom: Wydawnictwo POLWEN.

Wojtyła, K. (1961). Personalizm tomistyczny. Znak, 83, 664-675. 
